
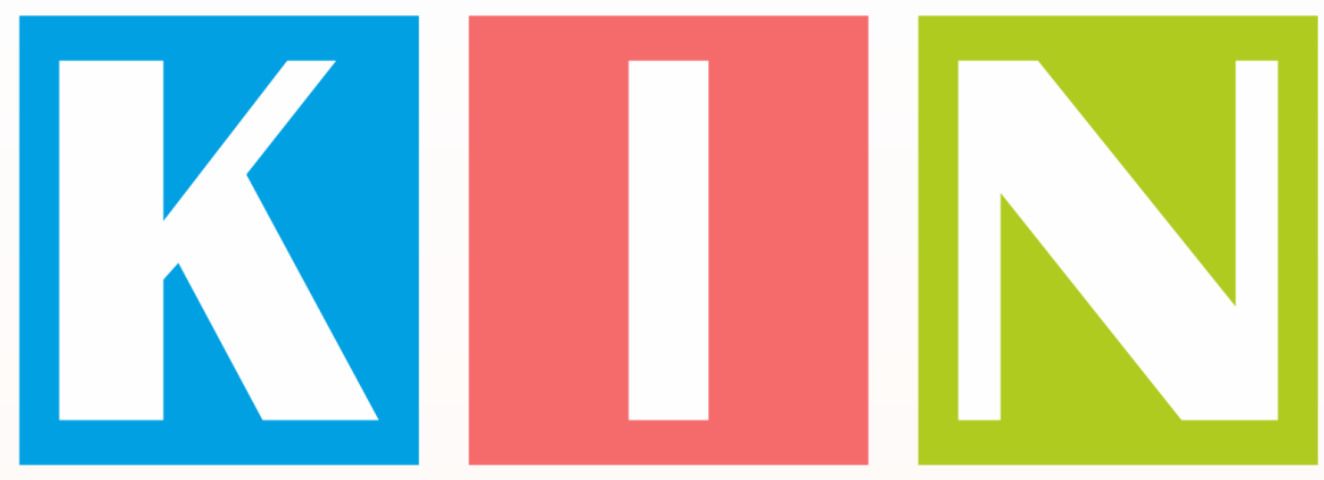

\title{
KIN Journal
}

\section{1, Volume 07, Issue 2}

\section{Cultural and Historical Heritage:}

\section{Preservation, Presentation, Digitalization}

\author{
Културно-историческо наследство: \\ опазване, представяне, дигитализачия
}

Культурное и историческое наследие:

сохранение, презентаиия, оиифровка

ISSN: $2367-8038$

http://www.math.bas.bg/vt/kin/

Publisher: Institute of Mathematics and Informatics, at the Bulgarian Academy of Sciences, Sofia, Bulgaria 
This work is subject to copyright. Permission to make digital or hard copies of portions of this work for personal or educational use is granted without fee, provided that the copies are not made or distributed for profit or commercial advantage and that the copies bear this notice and the full citation on the first page. To otherwise reproduce or transmit in any form or by any means, electronic or mechanical, including photocopying, recording, or by any information storage retrieval system or in any other way requires written permission from the publisher.

Volume 7, Issue 2, 2021, ISSN: 2367-8038, http://www.math.bas.bg/vt/kin/

Editors: Prof. PhD. Petko St. Petkov, Prof. PhD. Galina Bogdanova

Copy editors: Assist. prof. PhD. Nikolay Noev, Assist. prof. PhD. Kalina Sotirova-Valkova, Paskal Piperkov

(C) Editors, authors of papers, 2021

Published by: Institute of mathematics and informatics at the Bulgarian Academy of Sciences, Bulgaria, 1113, Sofia, 8 Acad. Georgi Bonchev Str.

Материалите в сборника са обект на авторско право. Разрешение за направа на електронни или хартиени копия на част или на цяла публикация за лично или обучително ползване се предоставя без заплащане, при условие, че копията не са направени или разпространявани с цел печалба или търговска изгода и че копията са съпроводени с това съобщение и пълно цитиране на първата страница. За копиране под друга фрорма, за препубликуване или публикуване на сървъри се изисква предварително специално разрешение и/или заплащане.

Том 7, брой 2, 2021, ISSN: 2367-8038, http://www.math.bas.bg/vt/kin/

Научни редактори: проф. д-р Петко Ст. Петков, проф. д-р Галина Богданова

Технически редактори: гл. ас. д-р Николай Ноев, ас. д-р Калина Сотирова-Вълкова, Паскал Пиперков

(С Авторски колектив, 2021

Научната поредица е регистрирана в НАЦИД с № 1209

Издание на: Институт по математика и информатика при Българска академия на науките, България, 1113, София, ул. "Академик Георги Бончев" бл. 8 


\section{Preface}

Cultural and Historical Heritage: Preservation, Presentation, Digitalization (KIN Journal) has been published since 2015. It is an open access, peer-reviewed, online journal published by the Institute of Mathematics and Informatics, BAS. The Editorial Board consists of world recognized researchers from different countries. It is included in the reference list of the National Center for Information and Documentation (NACID). The journal's issues are published regularly two times a year. Also special issues are published. We aim to bring important research work in field of preservation, digitalization and presentation of world and national cultural heritage. The language of publication is Bulgarian, English or Russian. Publication of papers is free-of-charge.

The journal publishes articles of interdisciplinary sciences:

- Digital Humanities

- Ethnology and Folklore

- History and Archeology

- Art Studies

- Computer Sciences

- Digital technologies

- Education

- Theology

This is an open access journal which means that all content is freely available without charge to the user or his/her institution. Users are allowed to read, download, copy, distribute, print, search, or link to the full texts of the articles in this journal without asking prior permission from the publisher or the author. This is in accordance with the BOAI definition of open access.

Open access has gained tremendous support from both authors, who appreciate the increased visibility of their work, as well as science institutions and funders, who value the societal impact of freely available research results.

\section{Free availability thanks to unrestricted online access}

Open access publications are freely available online to anyone, which maximizes the visibility, and thus the uptake and use of the work published. 


\section{Authors retain copyright}

The use of a Creative Commons License enables authors/editors to retain copyright to their work. Publications can be reused and redistributed as long as the original author is correctly attributed.

\section{Rapid publication}

A streamlined and easy to use online submission and production process enables quick review, approval and publication.

\section{No space constraints}

Publishing online means unlimited space for supplementary material including figures, extensive data and video footage.

\section{Citation tracking and inclusion in bibliographic databases}

Open access journals are tracked for impact factors and are deposited into bibliographic databases and institutional repositories without any embargo period just as traditional journals

Copyright licence: All articles are licenced via Creative Commons CC BY-NC-ND 4.0 licence.

\section{Publication Ethics and Publication Malpractice Statement}

(These guidelines are based on existing Elsevier policies and COPE's Best Practice Guidelines for Journal Editors)

\section{Peer Review Policy}

The journal maintain the highest standards of peer review while increasing the efficiency of the process. The practice of peer review is to ensure that only good science is published. It is an objective process at the heart of good scholarly publishing and is carried out by all reputable scientific journals. 


\section{Предговор}

Културно-историческо наследство: опазване, представяне, дигитализация (KIN Journal) излиза от 2015 г. Това е рецензирано онлайн списание с отворен достъп, което се издава от Института по математика и информатика, БАН. Редакционният съвет се състои от световно признати изследователи от различни страни. Включено е в референтния списък на НАЦИД. Изданията на списанието се публикуват редовно два пъти годишно. Също така се издават и специални броеве. Стремежа на авторите и редакторите е да се допринесе към изследователската дейност в областта на опазването, дигитализацията и представянето на световното и националното културно наследство. Езикът на изданието е български, английски или руски. Публикуването е безплатно.

Списанието публикува статии с интердисциплинарна насоченост в следните областти:

- Дигитални хуманитарни науки

- Етнология и фолклор

- История и археология

- Изкуствознание

- Компютърни науки

- Цифрови технологии

- Образование

- Богословие

Списанието е с отворен достъп, което означава, че цялото съдържание е безплатно достъпно за потребителя или неговата институция. Потребителите имат право да четат, изтеглят, копират, разпространяват, отпечатват, търсят или правят връзка към пълните текстове на статиите в това списание, без да искат предварително разрешение от издателя или автора. Това е в съответствие с дефиницията на BOAІ за отворен достъп.

Отвореният достъп получи огромна подкрепа както от авторите, които оценяват повишената видимост на работата си, така и от научните институции и финансиращите организации, които оценяват общественото въздействие на свободно достъпните резултати от научните изследвания.

\section{Безплатна наличност благодарение на неограничен онлайн достъп}

Публикациите с отворен достъп са свободно достъпни онлайн за всеки, което увеличава видимостта и по този начин възприемането и използването на публикуваната работа. 


\section{Авторите запазват авторските права}

Използването на лиценз Creative Commons позволява на авторите / редакторите да запазят авторските права върху своите произведения. Публикациите могат да се използват повторно и да се разпространяват, стига оригиналният автор да е правилно цитиран.

\section{Бърза публикация}

Рационализираният и лесен за използване онлайн процес на подаване позволява бърз преглед, одобрение и публикуване.

\section{Без ограничение на пространството}

Публикуването онлайн означава неограничено пространство за допълнителни материали, включително фигури, обширни данни и видеозаписи.

\section{данни}

Проследяване на цитирането и включване в библиографски бази

Списанията с отворен достъп се проследяват за фактори на въздействие и се депозират в библиографски бази данни и институционални хранилища без какъвто и да е период на ембарго, точно както традиционните списания

(C) Всички статии са достъпни под условията на Creative Commons CC BY-NC-ND 4.0 лицен3.

\section{Публикационна етика}

Публикационна етика (Тези насоки се основават на съществуващите политики на Elsevier и Насоките за най-добри практики на COPE за редактори на списания)

\section{Рецензионна политика}

Списанието поддържа най-високите стандарти за рецензиране, като същевременно повишава ефективността на процеса. Практиката на рецензиране е да се гарантира, че само добра научна продукция ще бъде публикувана. Това е обективен процес в основата на доброто научно публикуване и се извършва от всички реномирани научни списания. 


\section{Table of Content / Съдържание}

Preface

Предговор

$03-06$

Table of Content

Съдържание

$07-10$

Olena Kozakevych

Ethnolocal Features of Traditional Shirts "Sorochkas" in Transcarpathian Hutsul Region of the End XIX - Early XXI Centuries: Openwork Décor

$11-23$

Dimitar Ivanov Dobrevski, Russana Goleva

Challenges in Preserving the Orthodox Traditions in Bulgarian Icon Painting

Димитър Иванов Добревски, Русана Голева

Предизвикателства при опазване на православните традиции в българската иконопис

$24-31$

\section{Elena Sereva}

Plastic Decoration of Holy Doors from the Fund of the National Church Historical and Archaeological Museum of the Holy Synod - Elements and Symbolism

\section{Елена Серева}

Пластична украса на Свети двери от фонда на Националения църковен историкоархеологически музей при Светия Синод - елементи и символика

$32-50$

\section{Stefka Kancheva}

Old Testament Readings for the Feast Meeting of the Lord: A Hermeneutical Key for the Old Testament's Exegesis in the Orthodox Church

\section{Стефка Кънчева}

Старозаветните четива за Сретение Господне: Херменевтичен ключ за екзегезата на Стария Завет в Православната църква

$51-60$

\section{Stanimir Stoyanov, Asya Stoyanova - Doycheva, Todorka Glushkova}

Virtual-Physical Space "Bulgarian Cultural and Historical Heritage"

Станимир Стоянов, Ася Стоянова-Дойчева, Тодорка Глушкова

Виртуално-фризическо пространство „Българско културно-историческо наследство“ 
Kristian Milev, Georgi Kostadinov, Stefan Staynov, Asya Stoyanova-Doycheva

Intelligent Tourist Guide - Generating Ambient-Oriented Routes and Digital Classification of Elements of the Cultural and Historical Heritage of Bulgaria

Кристиан Милев, Георги Костадинов, Стефан Стайнов, Ася Стоянова-Дойчева

Интелигентен туристически екскурзовод - генериране на амбиент-ориентирани маршрути и дигитално класифициране на елементи от културното историческо наследство на България

$71-81$

Nevena Moraliyska, Todorka Glushkova, Mariya Grancharova-Hristova

Processing and Presentation of Knowledge about the Cultural-Historical and Natural Heritage of Bulgaria in an Intelligent Tourist Guide

Невена Моралийска, Тодорка Глушкова, Мария Грънчарова-Христова

Представяне и обработка на знания за културно-историческото и природното наследство на България в интелигентен туристически пътеводител

$82-93$

Sebiha Madanska, Stanimir Stoyanov, Asya Stoyanova-Doycheva

Digitalization of Bulgarian Residential Architecture in and around the Bulgarian Revival Period Typological Groups and Houses

Себиха Маданска, Станимир Стоянов, Ася Стоянова-Дойчева

Дигитализация на българската жилищна архитектура в и около периода на Възраждането типологични групи и къщи

$94-106$

Tsvetomira Ivanova

Ontology of Bulgarian Folklore

Цветомира Иванова

Онтология на българския фолклор

$107-114$

Mariya Grancharova-Hristova, Nevena Moralijska, Sebiha Madanska

Development of an Ontology in the Field of the Humanities

Мария Грънчарова-Христова, Невена Моралийска, Себиха Маданска

Разработване на онтология в областта на хуманитаристиката

$115-128$

\section{Pavel Hristov}

Development of FairDeal Platform

\section{Павел Христов}

Разработване на платформа FairDeal

\section{Petyo Krastev}

Ethnomusicological Field Research and Archiving 


\section{Петьо Кръстев}

Етномузиколожки терен и архивиране

\section{Galina Lukanova}

Preservation and Promotion of the Cultural-Historical Heritage and the Settlement Culture (Following the Example of the Town of Kableshkovo, Burgas District, Bulgaria)

\section{Галина Луканова}

Опазване и популяризиране на културно-историческото наследство и селищната култура (по примера на гр. Каблешково, област Бургас, България)

$145-150$

\section{Miroslava Taskova}

Digital and Printed Teaching Aids of Kyustendil Regional History Museum Programmes for Children мирослава Таскова

Дигиталните и печатните учебни помагала към програмите за деца на Регионален исторически музей - Кюстендил

\section{Galina Bogdanova, Liana Galabova}

Interdisciplinary and Intercultural Proving of Accessibility of Balkan Sacred Sites for People with Special Needs (Part 1)

\section{Галина Богданова, Лиана Гълъбова}

Интердисциплинарно и интеркултурно подсигуряване на достъпност на балканските свети места за хора със специални потребности (част 1)

$164-171$

\section{Vesela Vasileva Georgieva}

Wine in the Traditions of the Thracians: Modern Research and Manifestations

\section{Весела Василева Георгиева}

Виното в традициите на траките: съвременни изследвания и проявления

$172-180$

\section{Pavlina Vladeva}

Vasil Levski, Grandmother Dona Milina and the Troyan Revolutionary Activists

Павлина Владева

Васил Левски, баба Дона Милина и троянските революционни дейци

\section{Boyan Blazhev}

Visual Arts and Digital Technologies

\section{Боян Блажев}

Визуални изкуства и дигитални технологии 


\section{Mariyan Petrov}

Word Creation in Computer-Mediated Communication. Occasionalisms (False-Names) and Neologisms (Study based on examples on the social network „Facebook")

\section{Мариян Петров}

Словотворчеството в компютърно опосредстваната комуникация. Оказионализми (фралсоними) и неологизми (Изследване на базата на примери в социалната мрежа „Фейсбук“)

\section{Anna Angelova}

Phytonymic Lexics and Its Reflection in the Linguistic Picture of the World (Based on the Russian and Bulgarian Languages)

\section{Анна Ангелова}

Фитонимическая лексика и ее отражение в языковой картине мира (На материале русского и болгарского языков)

\section{Alexander Gorchev, Dimitar Dimitrov}

Conservation and Restoration of Molybdobulls from the Fund of the Archaeological Museum "Veliki Preslav"

\section{Александър Горчев, Димитър Димитров}

Консервация и реставрация на моливдовули от фронда на археологически музей „Велики Преслав"

\section{Evgeni Koev}

The Newly Discovered Monk Rock Cell Located between the Monk Rock Complexes "The Archangel" and "Krashtelnyata", which are Part of the Ivanovo Rock-Hewn Monasteries la New View on the Structure and Range of the Great Monastery "St Archangel Michael" at the Ivanovo Village/

\section{Евгени Коев}

Новооткрита монашеска скална килия между манастирските скални комплекси „Архангела“ и „Кръщелнята“ от Ивановските скални манастири /нов поглед към обхвата на Великата лавра „Архангела“ при с. Иваново/

\section{Mirena Todorova-Ekmekci}

Presenting and Promoting Cultural Heritage with Digital Media, Marketing Approaches and Methods. Good Examples.

\section{Мирена Тодорова-Екмекджи}

Представяне и популяризиране на културното наследство с дигитални медии, маркетингови подходи и методи. Добри примери. 

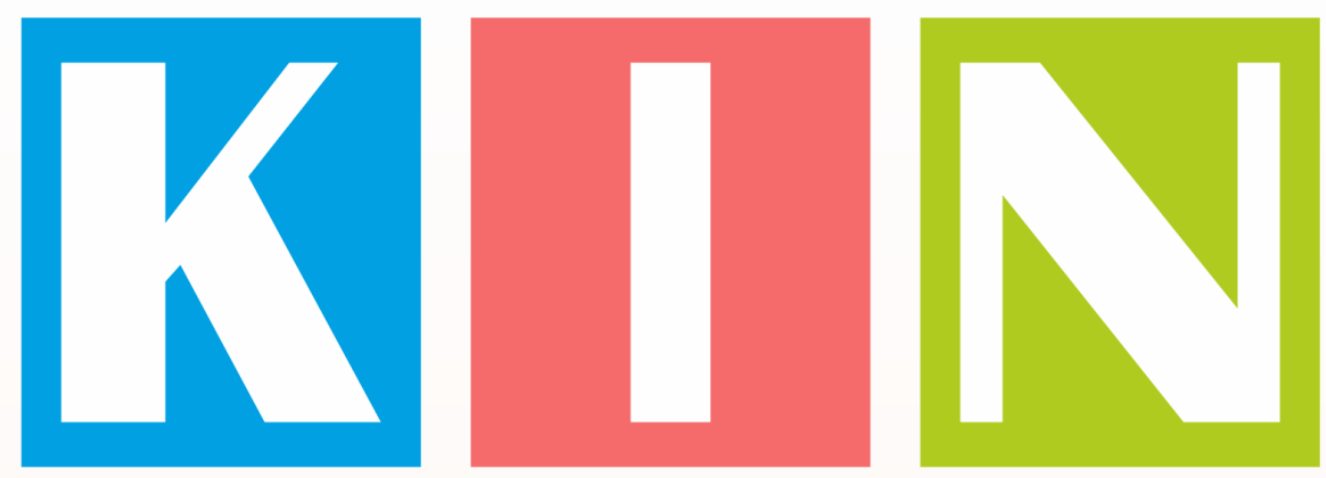

\section{KIN Journal, 2021, Volume 07, Issue 2}

Science Series Cultural and Historical Heritage: Preservation, Presentation, Digitalization Научна поредииа Културно-историческо наследство: опазване, представяне, дигитализаиия

Научная серия Культурное и историческое наследие: сохранение, презентаиия, оиидровка

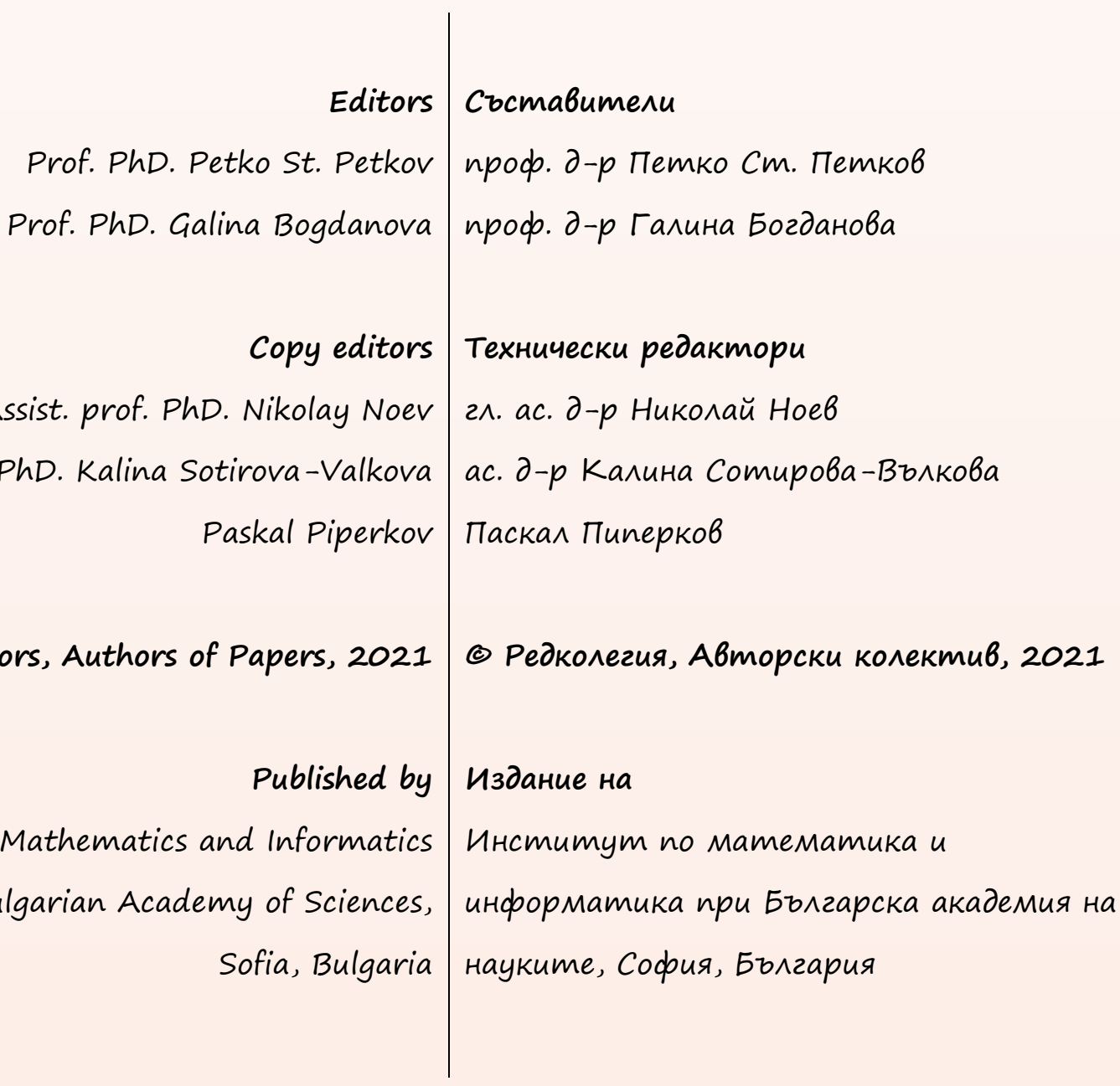

http://www.math.bas.bg/vt/kin/

ISSN: $2367-8038$ 